\title{
Business journals on China: a view from the west
}

\begin{abstract}
Steven F. Jackson
Examines the strengths, weaknesses and online availability of a variety of the major English-language business journals which have China as a major or their main focus.
\end{abstract}

There are well over 30 magazines and journals dedicated solely to the China market, and an even larger number which focus on East Asia and the Pacific Rim. Many of the China business periodicals, however, look remarkably similar, take their information from the same sources, and only the largest businesses can afford to subscribe to all. Some of these journals are indexed through online databases, some are abstracted, and some have their entire text available electronically. Others, including some of the best journals, are not available in any electronic form and might be missed by the researcher who only uses online searching. The best titles are covered in this article.

\section{The China Business Review (CBR)}

Published bi-monthly by the US-China Business Council, it is the premier China business journal. Packed with graphics and colour, its articles show much more depth than any other journal in the field, and is particularly sophisticated regarding investment in China. Issues average 60 pages, including advertisements. Its strength lies in its attention to regional coverage within China and specific businesses. Many of $C B R$ 's issues are thematic, devoted to a particular industry or sector, and $C B R$ often features interviews with prominent Americans and Chinese about US-China business relations. CBR lists recently signed contracts and deals between Chinese organisations and foreign firms. Several other periodicals do this as well, but $C B R$ 's list is the most comprehensive. Its trade and economic statistics are brief but well-presented. In the last two years, $C B R$ has expanded to include Hong Kong and Vietnam in its coverage. It is indexed online through a number of different sources, most comprehensively by ABI/Inform and Trade \& Industry Index on Dialog, BRS, Data-Star and others. 


\section{ABOUT THE AUTHOR}

Steven F. Jackson is a doctoral candidate in the department of political science, University of Michigan. He is also a research associate responsible for China for the Global Leadership Program of the University of Michigan Business School.

\section{China Trade Report (CTR)}

Published by Far Eastern Economic Review, CTR is a 16 page news monthly, with a scattering of photos and graphics. CTR's main strength lies in its knowledge of southern China, and bilateral commercial relations, and it has a regular column entitled Japan Brief which focuses on recent Sino-Japanese business deals. As the title implies, it emphasises trade, and regular import and export figures broken down by product type. It also includes a table of the latest exchange rates between Chinese Foreign Exchange Certificates (FEC) and major world currencies. It is partially indexed by Foreign Trade \& Economic Abstracts on Dialog and Data-Star.

\section{China Newsletter}

Published by Japan External Trade Organisation (Jetro), China Newsletter is one of the lesser known sources which is especially valuable for its Japanese perspective. Its accounts of the Chinese economy and Sino-Japanese joint ventures are good, and it lists recently signed Sino-Japanese investment and trade agreements based upon Japanese statistics and sources of information. China Newsletter does not contain the kind of business advice and "how to" information which CBR and Business China (see below) do, and it tends to emphasise economic rather than actual business issues. It is indexed in Key to Economic Literature, a Dutch English-language abstracting service which will also photocopy and mail articles for a fee. It is also selectively indexed in Foreign Trade \& Economic Abstracts. It should be noted, however, that China Newsletter's Japanese language equivalent, Chukoku keizai, is a monthly of nearly 200 pages, whereas China Newsletter is only a bi-monthly averaging 24 pages an issue.

\section{Business China $(B C)$}

One of Business International's many regional periodicals, $B C$ 's bi-weekly loose-leaf presentation, black-and-white printing and sparse graphics give it a no-nonsense appearance. Business China includes specific "how to" advice regarding trade and investment in China. It is particularly strong on trends in specific industries and the effect of policies for Beijing. It, too, lists recent Sino-foreign contracts, through fewer than $C B R$. $\mathrm{BC}$ also regularly reports the exchange rates in the swap centres of China. Business International also publishes Business Asia, which covers the entire Asian region, including China. Both are available online in full-text format through Mead Data Central since 1987, as well as PTS PROMT on Dialog, BRS and Data-Star, and indexed on Dialog's F\&S Index. 


\section{Country Report: China, North Korea}

Published by the Economic Intelligence Unit (EIU), now owned by Business International, this quarterly includes a one page summary, a three-page outlook, predicting issues likely to dominate the economy and polity of China, and a review section of some 20 pages which assesses the previous quarter's politics, economics and foreign trade with a few simple tables and graphs. Much of the factual information is available elsewhere, but the Country Report series is a consistent and reliable source of basic information on China, as well as over one hundred other countries. It has an annual Country Profile supplement which contains more background information.

\section{China-Britain Trade Review}

This is similar to China Newsletter in its bilateral focus. CBTR's trade statistics are based upon British customs sources. Like other journals, it tracks recent contracts, but it also regularly reports on the establishment of new Chinese organisations, corporations and bureaus. It is not indexed extensively, unfortunately.

\section{East Asia Express}

Many China business periodicals are broadening their coverage, and East Asia Express (formerly China Express) is one such example. Produced by NewsNet, a major producer of specialised newsletters and an online information vendor, East Asia Express contains business and contract news. Its full text is also available online, directly through NewsNet, or indirectly through PTS Newsletter database, available on Dialog and Data-Star.

\section{Legal periodicals}

There are a number of periodicals which focus on Chinese civil and commercial law. Among the best are China Law and Practice, a Hong Kong periodical described by one lawyer as "first rate", which translates the full text of new laws into English. China Laws for China Business, published by $\mathrm{CCH}$ Australia, is a six-volume loose-leaf set, and has periodic updates of new Chinese laws, though these sometimes lag behind announcements. Chinalaw is published by West Publishing, one of the largest legal publishers, and is available only with a West Publishing subscription or on Mead Data's Lexis database. It covers legislation relevant to foreign business. Chinalaw also translates legal documents from PRC. Other sources include the Longman Group's relatively new quarterly, China Current Laws, and the American Bar Association's quarterly, China Law Reports, which is indexed online through Wilsonline's Index to Legal Periodicals. These journals notwithstanding, there is no single, comprehensive source to turn to for information on Chinese laws. As one lawyer involved in China business states, "One of the main problems is that there is no central source of Chinese-language documents, let alone Englishlanguage documents containing all the laws we need to be concerned with". 


\section{- News sources}

Asian Wall Street Journal (AWSJ) and Asian Wall Street Journal Weekly

Published since 1979, AWSJ is rapidly becoming a leading source of current and in-depth China business information. Its format is patterned directly after its parent publication and $A W S J$ has bureaux in Beijing and elsewhere in Asia. Mead Data Central indexes and abstracts these publications online. PTS PROMT has a full-text version, and AWSJ is indexed by Trade \& Industry Index and F \& S Index.

\section{Far Eastern Economic Review (FEER)}

The leading news weekly magazine for Asia, FEER has been published in Hong Kong since 1946. Its strength lies in its economic and political reporting throughout the region, with bureaux in all of the major capitals. FEER is now owned by Dow Jones, which also owns the Asian Wall Street Journal. FEER's Hong Kong base sometimes influences its reporting on the Crown Colony, and despite the magazine's tribulations (it is banned in Singapore), it remains the Asia news weekly. Each issue summarises the activities of area financial markets, and its regular column Traveler's Tales, accounts of miswritten English in Asia, has been a source of amusement for expatriates for years. Indexed by Business Periodicals Index on Wilsonline, Academic Index (available on Dialog and a number of other services), and Trade \& Industry Index, with full text available though Nikkei Telecom Japan News \& Retrieval.

\section{East Asian Business Intelligence}

A newsletter published by International Executive Reports in Washington DC, giving details of business opportunities including government tenders. It is available online directly from NewsNet.

\section{East Asian Executive Reports}

Also from International Executive Reports, East Asian Executive Reports concentrate on business practice such as contracts and taxation in the region. Indexed in ABI/Inform, which is available on Dialog, BRS and other services, as well as full text through NewsNet and Mead Data Central, and indexed on ABI/Inform and Legal Resources Index on Dialog.

\section{China Daily}

An English-language daily published in Beijing, China Daily began in 1981. It has a regular business section every Monday, and its cultural notes can be useful for the expatriate in China, as well as its listing of swap centre exchange rates. China Daily regularly reports on agreements, letters of intent and other foreign investment in China, as well as uncritical reporting on the official Chinese government positions. China Daily, along with Xinhua news releases, are two of the major sources of business information in specialised trade and industry magazines which are not China-specific. It is partially indexed by Infomat International Business index on Dialog. 


\section{China's Foreign Trade}

Also an English-language Chinese publication, China's Foreign Trade started in 1956 and is largely a thinly veiled advertisement for Chinese products. It is also relatively cheap, $\$ 43.50 /$ year for institutions, less for individuals.

In addition, there are a number of smaller newsletters and other periodicals devoted to China business. Many are, however, quite expensive. For example, Business International's China Hand costs $\$ 1,400$ for a two-volume binder set with quarterly updates. China Hand provides the full text of new laws in China, way of doing business, lists of organisations, as well as a general country introduction. Mead Data Central offers it online. (See Richard Breecher's review of China Hand in China Business Review MayJune 1990, p.49). Business International also puts out a semi-annual China Market Atlas, which has recently changed its name to New Asian Market Atlas. Welt Publishing's China Business and Trade is a loose-leaf semi-monthly costing \$237 a year. It contains very brief announcements of new contracts and deals with China, as well as Chinese government plans for new projects. Other publications include China Market, published by Economic Information and Agency in Hong Kong, a monthly costing \$56 a year, not to be confused with China Market: the Businessman's Guide to the China Market, which is published by East-West Trade Publications in New York. China Letter, published by the Asia Letter Group in Hong Kong, is a somewhat chatty typescript monthly for \$175 a year.

There is also China Economic Report, China Report, China Enterprise, and China Sources. In addition, there is a small number of magazines about specific sectors in China, such as China AgriBusiness Report, a semi-monthly from Hong Kong costing \$595 a year, China Informatics, a loose-leaf computer-related journal from Hong Kong (\$450 for 24 issues a year), China Oil, China Transport, Medical China and Medical China Newsfile. Finally, there are a few newsletters such as Jardine Fleming's China which have restricted circulation and are not available for general subscription. The total number of China business periodicals probably reaches nearly forty, not to mention the dozens of Chineselanguage periodicals.

Quantity of information does not necessarily translate into quality, however, and price does not always reflect value. As one business analyst put it, "The quality of China business information available in Hong Kong is really very good, but the actual Chinese sources of business information are not good". Another analyst expressed the opinion that "there's a lot more chaff than wheat out there". The downturn in China business has, of course, taken its toll upon the large number of China business periodicals. As one China business watcher said, "The field is narrowing now, and we are seeing less published than before". Among the periodicals which have recently ceased publication are Intertrade, China International Business, China Handel, a German business periodical, and the EuroAsia Business Review, associated with INSEAD. MOR China Letter has merged recently with ChinaTrade of Cambridge, Massachusetts. For the cost-conscious business, the need to concentrate resources on the best quality China business periodicals could lead to the demise of many of the smaller publications. 


\section{- Periodical list and addresses}

Asian Wall Street Journal

Daily except Sat. and Sun., \$440 pa (airmail postage from Hong Kong) to the United States. The Asian Wall Street Journal, GPO Box 9825, Hong Kong.

\section{Business China}

Bi-weekly, \$560pa. Business International Corporation, 215 Park Ave. South, New York, New York 10003, USA.

\section{China AgriBusiness Report}

Semi-monthly, \$595 pa. China AgriBusiness Report, Asia Letter Group, GPO Box 10874, Hong Kong. In the United States: c/o Worldway Postal Center, Los Angeles, CA 90009, USA.

\section{China-Britain Trade Review}

Monthly, £100 pa. Sino-British Trade Council, 5F Abford House, 15 Wilton Road, London SW1V 1LT.

\section{China Business and Trade}

Semi-monthly, \$249 pa. Welt Publishing, 1413 K St., NW Suite 800, Washington DC 20036, USA.

\section{China Business Review}

Bi-monthly, \$96pa. 1818 N. St., NW Suite 500, Washington DC 20036, USA.

\section{China Computer World}

Fortnightly, \$48 pa. Technology Information Research Institute, 74 Lugu Cun Lu, PO Box 750, Beijing 100039, China.

\section{China Current Laws}

Quarterly, \$225 pa. Longman Group (Far East), 18F Tong Chang St., Quarry Bay, Hong Kong.

\section{China Daily}

Daily, \$140 pa. China Daily Distribution, 15 Mercer St., New York, New York 10013, USA. 
China Economic Report

Quarterly, \$165 pa. World Reports, 280 Madison Ave, Suite 1206, New York, New York 10016, USA.

\section{China Economic Review}

Semi-annual, \$80 pa. JAI Press, 55 Old Post Road No. 2, Box 1678, Greenwich CT 06836, USA.

\section{China's Foreign Trade}

Monthly, \$38.50 for individuals, \$43.50 for institutions. Guoji Shudian, PO Box 399, Beijing, China.

\section{China Hand}

Quarterly, \$1,400 pa. Business International, 215 Park Ave. South, New York, New York 10003, USA.

\section{China Informatics (formerly EDP Report)}

24 issues/year, \$450. International Data Corporation China, 903 Citicorp Center, 18 Whitfield Road, Causeway Bay, Hong Kong, or in the USA: c/o 5 Speen St., Framingham, MA 01701, USA.

\section{China Law Reporter}

Quarterly, \$43 pa. American Bar Association, International Law and Practice Section, 750 N. Lake Shore Dr., Chicago, IL 60611, USA.

\section{China Laws for China Business}

Irregular (approximately 10 pa). CCH Australia, PO Box 230 North Ryde, NSW 2113, Australia.

\section{China Letter}

Monthly, \$175 pa. Asia Letter Group, GPO Box 10874, Hong Kong.

\section{China Market}

Monthly, \$56 pa. Economic Information \& Agency, 342 Hennesy Rd 10-F, Hong Kong.

China Market: The Businessman's Guide to the China Market

Bi-monthly, \$50. East-West Trade Publications, 61 W. 62nd St., No. 4E, New York, New York 10023, USA. 
China Media Book: China's Advertising Rates and Media

Biennial, £75. Anglo-Chinese Publications, 17 Belmont, Lansdown Rd., Bath, Avon BA1 5D2.

\section{China Newsletter}

Bi-monthly, \$80 pa. Jetro, 2-5 Toranomon 2-chome, Minato-ku, Tokyo 105, Japan.

\section{China Sources}

Monthly, \$50 pa. China Media, c/o Wordwright Enterprises, 1020 Church St., Box 3062 Evanston, IL 60204, USA.

\section{China Trade Report}

Monthly, \$330 pa. c/o Far Eastern Economic Review, GPO Box 160, Hong Kong.

Country Report: China, North Korea

Quarterly, \$145 pa. Economist Publications, 40 Duke Street, London W1M 1DW.

\section{East Asian Business Intelligence}

Semi-monthly, \$295 pa. International Executive Reports, 717 D St. NW Suite 300, Washington, DC 20004, USA.

East Asian Executive Reports

Monthly, \$395 pa. International Executive Reports, 717 D St. NW Suite 300, Washington, DC 20004, USA.

Far Eastern Economic Review

Weekly, \$175 pa (airmail). Far Eastern Economic Review, GPO Box 160, Hong Kong.

New Asian Market Atlas

Semi-annual, \$385. Business International, 215 Park Ave. South, New York, New York 10003, USA. 